\title{
USING EMPLOYEE EMPOWERMENT TO ENCOURAGE ORGANIZATIONAL COMMITMENT IN THE PUBLIC SECTOR
}

\author{
Izabela Marzec
}

$J P M * *$

JOURNAL

OF POSITIVE

MANAGEMENT

Vol. 5, No. 2, 2014, pp. 43-52 (c) Copyright by Wydawnictwo Naukowe Uniwersytetu Mikołaja
Kopernika ISSN 2083-103X

http://dx.doi.org/ 10.12775/JPM.2014.012

\begin{abstract}
Purpose: Changes in the public sector and the recognition of the concept of New Public Management have led to wider introduction of employee empowerment programs in public organizations. It is assumed that today the success of public organizations depends on the application of modern HRM methods oriented towards encouraging commitment and initiative of employees. The paper tries to answer the questions about the level of employee empowerment and organizational commitment of employees in the public sector and whether employee empowerment is related to organizational commitment.
\end{abstract}

Methodology: This goal is reached by presenting the results of empirical research carried out in public organizations. Survey research was carried out at the end of 2012. The sample consisted of 318 employees of public organizations operating in southern Poland.

Findings: The survey revealed that the level of employees' organizational commitment is high in Polish public organizations. The analysis also showed that the level of employee empowerment is high in public organizations. The conducted research also proved that employee empowerment is positively connected with organizational commitment of employees in Polish public organizations.

Implications and limitations: The results indicated that the use of employee empowerment can bring the required results such as the increase of employees' emotional attachment to the organization and loyalty towards the organization. But its influence on employee's intentions to leave the organization is very limited.

Originality/value of the paper: There is still little empirical research on this subject, particularly in the public sector.

Keywords: employee empowerment, organizational commitment, public sector

Paper Type: Research paper 
USING EMPLOYEE EMPOWERMENT

TO ENCOURAGE

Izabela Marzec

\section{Introduction}

Changes in Polish public organizations require paying special attention to these instruments of Human Resource Management which can help employees to face emerging new challenges, and to stimulate their initiative and commitment. Simultaneously, a growing interest in using achievements of Positive Organizational Scholarship - POS) can be observed in Human Resource Management. POS is based on achievements of positive psychology which emphasizes positive aspects of functioning of an individual in the organization. Although in the last decade negative aspects of organizational impact on employees have mostly been stressed, today more frequently researchers emphasize the necessity to focus on positive experiences of employees, their conditions and results. According to POS, positive emotions and experiences of employees are underestimated both in theory and practice of HRM. The important domains of POS also encompass such issues as organizational commitment and employee empowerment. It should also be emphasized that there is still little empirical research on this subject, particularly in the public sector. This paper tries to answer the questions about the level of employee empowerment and organizational commitment and whether employee empowerment is related to organizational commitment. This goal will be reached by presenting the results of literature study and empirical research concerning employee empowerment and organizational commitment carried out in the public sector.

\section{Organizational commitment of employees in the public sector}

Becker was a precursor of research into organizational commitment (Becker, 1960: 32-42). His works were continued by Mowday, Steers and Porter, but in contrast to Becker, they emphasized the importance of an emotional element in organizational commitment, defining it as the power of an employee's ties and his identification with the organization (Mowday et al., 1979: 226). Also in Polish literature on the subject, the issue of organizational commitment arouses great interest of researchers. Juchnowicz defines organizational commitment as an employee's identification with an organization, its aims and values, desire to belong to the organization and their readiness to spare no effort for the organization (Junchnowicz, 2010: 58). Today Meyer and Allen's model is generally accepted in empirical research. It encompasses three dimensions, i.e. (Meyer and Allen, 1990: 2-3):

- Affective commitment reflecting emotional attachment of the employee to the organization,

- Continuance commitment which concerns employee-perceived costs connected with leaving the organization,

- Normative commitment which is based on the feeling of obligation to stay in the organization, i.e. the employee's loyalty towards the organization. 
This model has been successfully used in a lot of empirical research, which proved that organizational commitment provides numerous benefits to employees and the organization, e.g. it positively influences employee performance, their work satisfaction and career success (Sager and Johnston, 1989: 34-35; Riketta, 2002: 261-263). Organizational commitment of employees depends on various organizational factors. The results of empirical research suggest that such characteristic features of public organizations as extended hierarchical structures, bureaucratic culture and centralized process of decision making can negatively affect organizational commitment of employees (Rowlinson, 2001: 670). Job characteristics are also important conditions of organizational commitment, e.g. autonomy, task identity, required skills variety, etc. Research conducted among employees of public and private organizations in the USA showed that precisely defined but challenging tasks enhance employees' organizational commitment (Flynn and Tannenbaum, 1993: 110-111). This research also suggests that employees of public organizations expect smaller autonomy than employees in private organizations (Flynn and Tannenbaum, 1993: 113). However, the increase of autonomy leads to the enhancement of employees' sense of responsibility for results, which in turn allows to partly replace top-down, hierarchical control with self-control, which is particularly important in an unstable environment of public organizations. It should also be stressed that research carried out in the public sector in Hong Kong proved that the lack of organizational commitment of employees can be a serious barrier for changes in public organizations (Rowlinson, 2001: 672). Real employees' commitment in the process of changes is an important factor of their success. Many researchers emphasize that employees of public organizations are guided by the need to serve the community and they want to contribute not only to the success of the organization but also to the welfare of the society. They are often deeply committed in their actions.

\section{Employee empowerment - the concept and its importance in public organizations}

There are many definitions of the notion of employee empowerment in the literature on the subject. This problem stems from the multidimensional nature of the concept as well as the variety of contexts in which the concept is applied. The concept of empowerment may be considered from two different but interrelated perspectives, i.e. organizational and individual (Bratnicki et al., 2007: 36; Marzec, 2005: 41). Individual approach is focused on managerial actions and practices aimed at involving employees in management of the organization, as well as the increase of their autonomy and responsibility, which result in improvement of their performance. A simple definition of employee empowerment considered from organizational perspective is proposed by Paul, Niehoff and Turnley. In
USING EMPLOYEE EMPOWERMENT

TO ENCOURAGE

Izabela Marzec 
USING EMPLOYEE EMPOWERMENT TO ENCOURAGE

Izabela Marzec their opinion, employee empowerment consists in giving power, control and responsibility to subordinates at lower levels of organizational hierarchy (Paul et al., 2000: 472). According to Bowen and Lawler employee empowerment is not only based on the delegation of power but also on sharing knowledge and information with employees, as well as performance-based rewards (Bowen and Lawler, 1992: 418). Many researchers claim that comprehensive organizational changes encompassing both the structure and organizational systems are needed to empower employees. For researchers representing individual approach, organizational factors are the only predictors of employee empowerment. According to Conger and Kanungo, employee empowerment is the process of enhancing feelings of self-efficacy among organizational members through identification of the conditions provoking incapacity and elimination thereof using both organizational practices as well as informal techniques of ensuring self-efficacy information (Conger and Kanungo, 1988: 475-489). Their work was continued by Thomas and Velthouse, who developed the so-called cognitive model of empowerment, which includes four dimensions, i.e. (Thomas and Velthouse, 1990: 672-679):

- Choice, which refers to employee-perceived possibility to decide about the methods and instruments of their work tasks execution,

- Competency, which is an employee's belief that he/she is able to perform his/her work properly,

- Meaningfulness, which concerns employee-perceived value of their work aims and tasks in reference to their own norms and values,

- Impact, which is an employee's subjective evaluation of the extent to which he/she can influence organizational functioning by his/her actions.

Empirical research carried out in the public sector allowed to confirm this model regarding employees of public organizations (Cho and Faerman, 2010: 44). In contrast to organizational approach this model stresses the subjective, cognitive aspects of employee empowerment. However, although all presented dimensions concern employees' subjective feelings, they occur as the reaction to the objective characteristics of their work environment.

It has been found that employee empowerment brings positive results for both organizations and employees, e.g. it stimulates employees' initiative and entrepreneurial behaviours, it increases their motivation and work satisfaction, and as a consequence it enhances organizational performance (Ugboro and Obeng, 2000: 247; Bratnicki et al., 2007: 42-49). Because of these numerous advantages, many Western enterprises have been introducing various employee empowerment programs since the 1990s.

Because of the changes in the public sector and the growing popularity of New Public Management, employee empowerment programs are being introduced also in public organizations in the USA, Australia, Canada and many European 
countries, e.g. Great Britain, Norway, Sweden, and Poland (Fernandez and Moidogaziev, 2012: 155). These programs are aimed at improving organizational performance through positive impact of employee empowerment on employees' commitment, work satisfaction, proactiveness and initiative. NPM emphasized the importance of professional management, decentralization, entrepreneurship, strategic planning and market mechanisms as key factors deciding about effectiveness of public organizations. It has been assumed that the success of public organizations depends largely on the use of modern methods and instruments of HRM, usually applied in private organizations. Some researchers claim that employee empowerment can be an effective HRM strategy aimed at the enhancement of transformation processes of bureaucratic public organizations (Cho and Faerman, 2010: 34). According to Strużyna, employee empowerment is an important element of changes appearing in employment area in European public organizations (Strużyna, 2009: 274).

On the other hand, due to the specific character of the public sector, practical adaptation of employee empowerment programs to the needs of public organizations may prove difficult. High level of formalization, ambiguity of aims, external limitations in flexibility of rewarding can decrease effectiveness of employee empowerment in the public sector (Fernandez and Moidogaziev, 2012: 156). Important factors which can make it hard to empower employees of public organizations also include limited autonomy of employees, the scope of work tasks often directed by law, specialization, hierarchy, top-down control, tendency to use authoritarian management style, etc. Taking into account literature study and previous empirical findings the following research hypotheses have been formulated:

H1: The level of employees' organizational commitment is high in Polish public organizations.

H2: The level of employee empowerment is low in Polish public organizations. H3: The level of employee empowerment is positively related to the level of employees' organizational commitment in Polish public organizations.

\section{Research method and results}

Empirical research was carried out at the end of 2012. The sample consisted of 318 employees of public organizations operating in southern Poland. Employee empowerment was measured with the scale created by Spreitzer (Spreitzer, 1995: 1464-5). Organizational commitment was measured with Allen and Meyer's scale (Allen and Meyer, 1990: 7). The questions were categorized and the respondents indicated a digit on the seven-grade Likert scale (from 1 - strongly disagree to 7 - strongly agree). 
USING EMPLOYEE EMPOWERMENT TO ENCOURAGE

Izabela Marzec

Table 1.

Descriptive statistics of organizational commitment
Most of the respondents were women $60 \%$ (85.8\%). The sample structure according to 'educational qualification' of the respondents can be presented as follows: $41.8 \%$ of the participants held Master degrees, $45.0 \%$ Bachelor's degrees and $10.7 \%$ of the participants had secondary education. The respondents with other 'educational qualification' constituted $2.5 \%$ of the sample. Regarding the age of employees the sample's structure can be presented as follows: respondents aged 18 to $26-20.8 \%$, aged 27 to $34-26.4 \%$, aged 35 to $43-22.6 \%$, aged 44 to $53-24.2 \%$, and $6 \%$ of respondents were aged 54 and above. $44 \%$ of the respondents were employed in public administration, $21.4 \%$ in education and $16.7 \%$ in public health care institutions. The share of respondents employed in organizations conducting other kinds of activity did not exceed 5\% (in total 17.9\%). Data was processed by means of SPSS 20.0. In order to test the constructed hypotheses, descriptive statistics, Pearson's correlation analysis were applied.

The obtained results indicate a relatively high level of organizational commitment of the respondents: the mean general rating of overall organizational commitment was 4.24 on the 7 -point scale (median 4.22) (see Table 1). The dimension of continuance commitment received the highest mean rating of 4.53 (median 4.50). Affective commitment was also rated high, i.e. the mean score was 4.32 (median 4.42). Normative commitment was significantly lower rated by employees, i.e. mean score was 3.87 (median 4.00). To sum up, the results do not give reasons to reject the first hypothesis that the level of employees' organizational commitment is high in Polish public organizations.

\begin{tabular}{lcccccc}
\hline Variable & Mean & Median & $\begin{array}{c}\text { Standard } \\
\text { deviation }\end{array}$ & Range & $\begin{array}{c}\text { Mini- } \\
\text { mum }\end{array}$ & $\begin{array}{c}\text { Maxi- } \\
\text { mum }\end{array}$ \\
\hline $\begin{array}{l}\text { Affective } \\
\text { commitment }\end{array}$ & 4.32 & 4.42 & 1.17 & 6.00 & 1.00 & 7.00 \\
\hline $\begin{array}{l}\text { Continuance } \\
\text { commitment }\end{array}$ & 4.53 & 4.50 & 1.13 & 6.00 & 1.00 & 7.00 \\
\hline $\begin{array}{l}\text { Normative } \\
\text { commitment }\end{array}$ & 3.87 & 4.00 & 1.30 & 6.00 & 1.00 & 7.00 \\
\hline $\begin{array}{l}\text { Organizational } \\
\text { commitment (overall) }\end{array}$ & 4.24 & 4.22 & 1.00 & 5.50 & 1.50 & 7.00 \\
\hline
\end{tabular}

The conducted analysis showed that in general the surveyed employees gave high ratings to the level of employee empowerment: the mean score was 5.06 points on the 7-point scale (median 5.08) and the ratings were not very diverse (standard deviation 0.87) (see Table 2). The levels of competence and meaningfulness of work were rated very high (mean scores were 5.94 and 5.86, respectively). The dimension of choice was clearly lower rated by employees (mean 4.58; median 4.67). The dimension of impact received the lowest ratings - the mean score was 
only 3.88 (median 4.00). It should be noticed that there are significant differences between the levels of particular dimensions of employee empowerment but the general level of employee empowerment was evaluated relatively high. Therefore, the obtained results did not confirm the second hypothesis that the level of employee empowerment is low in Polish public organizations.

\begin{tabular}{lcccccc}
\hline Variable & Mean & Median & $\begin{array}{c}\text { Standard } \\
\text { deviation }\end{array}$ & Range & Minimum & Maximum \\
\hline Meaningfulness & 5.86 & 6.00 & 1.08 & 6.00 & 1,00 & 7.00 \\
\hline Competency & 5.94 & 6.00 & 0.88 & 6.00 & 1.00 & 7.00 \\
\hline Choice & 4.58 & 4.67 & 1.28 & 6.00 & 1.00 & 7.00 \\
\hline Impact & 3.88 & 4.00 & 1.56 & 6.00 & 1.00 & 7.00 \\
\hline $\begin{array}{l}\text { Employee empower- } \\
\text { ment (overall) }\end{array}$ & 5.06 & 5.08 & 0.87 & 4.58 & 2.42 & 7.00 \\
\hline
\end{tabular}

In the next step the relationships between employee empowerment and organizational commitment of employees were examined (see Table 3). Pearson's correlation analysis revealed that there were significant positive correlations between employee empowerment and organizational commitment - the general rating of employee empowerment was clearly positively correlated with the general rating of employees' organizational commitment (0.33).

\begin{tabular}{|c|c|c|c|c|c|c|c|c|c|}
\hline Variables & 1. & 2. & 3. & 4. & 5. & 6. & 7. & 8. & 9. \\
\hline \multicolumn{10}{|l|}{ 1. Meaningfulness } \\
\hline 2. Competency & $0.45^{* *}$ & & & & & & & & \\
\hline 3. Choice & $0.28 * *$ & $0.29 * *$ & & & & & & & \\
\hline 4. Impact & $0.28 * *$ & $0.20 * *$ & $0.60 * *$ & & & & & & \\
\hline $\begin{array}{l}\text { 5. Employee empo- } \\
\text { werment (overall) }\end{array}$ & $0.65 * *$ & $0.59 * *$ & $0.79 * *$ & $0.80 * *$ & & & & & \\
\hline $\begin{array}{l}\text { 6. Affective commit- } \\
\text { ment }\end{array}$ & $0.42 * *$ & $0.12 *$ & $0.26 * *$ & $0.35 * *$ & $0.41 * *$ & & & & \\
\hline $\begin{array}{l}\text { 7. Continuance com- } \\
\text { mitment }\end{array}$ & $0.23 * *$ & 0.04 & 0.04 & 0.02 & 0.10 & $0.42 * *$ & & & \\
\hline $\begin{array}{l}\text { 8. Normative com- } \\
\text { mitment }\end{array}$ & $0.33 * *$ & 0.09 & $0.20 * *$ & $0.26^{* *}$ & $0.31 * *$ & $0.71 * *$ & $0.49 * *$ & & \\
\hline $\begin{array}{l}\text { 9. Organizational } \\
\text { commitment (overall) }\end{array}$ & $0.39 * *$ & 0.10 & $0.20 * *$ & $0.25^{* *}$ & $0.33^{* *}$ & $0.85^{* *}$ & $0.75 * *$ & $0.89 * *$ & \\
\hline
\end{tabular}

USING EMPLOYEE EMPOWERMENT TO ENCOURAGE

Izabela Marzec

Table 2. Descriptive statistics of employee empowerment
Table 3.

Pearson's correlations between organizational commitment and employee empowerment

$* p<0.05, * * p<0.01$ 
USING EMPLOYEE EMPOWERMENT TO ENCOURAGE

Izabela Marzec
The strongest correlations were observed between affective commitment and meaningfulness of work (0.42) and between affective commitment and impact (0.35) as well as between meaningfulness and the general rating of employees' organizational commitment (0.39) and between affective commitment and the general rating of employee empowerment (0.41). Weaker correlations appeared between normative commitment and employee empowerment. Continuance commitment was only significantly associated with meaningfulness of work (0.23). However, the results do not give reasons to reject the third hypothesis (H3) that the level of employee empowerment is positively related to the level of employees' organizational commitment in Polish public organizations.

\section{Discussion and conclusions}

The obtained results do not give reasons to reject the first formulated hypothesis (H1) that the level of employees' organizational commitment is high in Polish public organizations. However, it should be noticed, that continuance commitment was the highest rated dimension of organizational commitment. This fact indicates that many employees rather stay in their organizations due to the fear of leaving them and becoming unemployed than because of their loyalty.

Against the second hypothesis (H2), the analysis showed that the level of employee empowerment is high, thus this hypothesis was rejected. But it should be stressed that there were significant differences in the employees' evaluation of the levels of particular dimensions of employee empowerment. Moreover, the results clearly indicated that respondents had a low sense of impact on the functioning of their organizations. It may be the result of centralization of decision making processes in these organizations. Low sense of impact can lead to the disappearance of employees' initiative and decrease of employee's sense of responsibility for organizational performance.

The conducted research also proved that employee empowerment is positively connected with organizational commitment of employees in Polish public organizations (H3). Pearson's correlation analysis showed that there were significant relationships between employee empowerment and organizational commitment. Simultaneously, the results revealed that employee empowerment had the strongest correlation with affective commitment of employees. Its relationship with normative commitment is weaker and with continuance commitment is poor. This indicates that the use of employee empowerment can bring the required results such as the increase of employees' emotional attachment to the organization and loyalty towards the organization. But its influence on employee's intentions to leave the organization will rather be quite limited. Moreover, probably these results will be weaker in the group of employees who remain in the organization because of their fear to leave it. 
To conclude, changes in Polish public organizations and challenges connected with them require real and deep organizational commitment of their employees. This commitment should be based on their sense of responsibility for results and willingness to put considerable effort into organizational success. HRM needs such instruments that will allow to use the whole potential of employees, enhancing their commitment and which will give employees the possibility of self-fulfillment and making their own contribution to organizational success. Undoubtedly, employee empowerment could be one of such instruments.

\section{References}

Allen, N.J., Meyer, J.P. (1990), "The measurement and antecedents of affective, continuance and normative commitment to the organization", Journal of Occupational Psychology, Vol. 63 No. 1, pp. 1-18. DOI: 10.1111/j.2044-8325.1990.tb00506.x

Becker, H.S. (1960), "Notes on the concept of commitment", American Journal of Sociology, Vol. 66, pp. 32-42. DOI: 10.1086/222820

Bowen, D.E., Lawler, E.E (1994), "The Empowerment of Services Workers: What, Why, How, and When", in: Schneier, C.E., Russell, C.J., Beatty, R.W., Baird, L.S. (Eds.), The training and development sourcebook, HRD Press Inc., Amherst, pp. 413-422.

Bratnicki, M., Marzec, I., Zabierowski, P., Kulikowska-Mrożek, M. (2007), "Empowerment and Entrepreneurship: Conceptual Issues and Empirical Tests", Journal of Economics and Management, No. 3, pp. 35-54.

Cho, T., Faerman, S.R. (2010), "An integrative approach to empowerment. Construct definition, measurement, and validation", Public Management Review, Vol. 12 No. 1, pp. 33-51. DOI: 10.1080/14719030902798610

Conger, J.A., Kanungo, R.N. (1988), "The empowerment process: Integrating Theory and Practice", Academy of Management Review, Vol. 13 No. 3, pp. 471-482.

DOI: $10.2307 / 258093$

Fernandez, S., Moidogaziev, T. (2012), “Using Employee Empowerment to Encourage Innovative Behavior in the Public Sector", Journal of Public Administration Research and Theory, Vol. 23 No. 1, pp. 155-187.

Flynn, D.M., Tannenbaum, S.I. (1993), "Correlates of organizational commitment: Differences in the public and private sector", Journal of Business and Psychology, Vol. 8 No. 1, pp. 103-116. DOI: 10.1007/BF02230396

Juchnowicz, M. (2010), „Human capital management and the level of employee commitment" (,Zarządzanie kapitałem ludzkimi a poziom zaangażowania pracowników”), Human Resource Management (Zarządzani Zasobami Ludzkimi), No. 3-4, pp. 58-66.

Marzec, I. (2005), „Motivating by employee empowerment” (,Motywowanie przez upełnomocnienie"), Human Resource Management (Zarzadzanie Zasobami Ludzkimi), No. 3-4, pp. 41-52.

Mowday, R.T, Steers, R.M., Porter L.W. (1979), “The measurement of organizational commitment", Journal of Vocational Behavior, Vol. 14 No. 2, pp. 224-247.

DOI: 10.1016/0001-8791(79)90072-1

Paul, R.J., Niehoff, B.P., Turnley, W.H. (2000), "Empowerment, expectations, and the 
USING EMPLOYEE EMPOWERMENT

TO ENCOURAGE

Izabela Marzec psychological contract - managing the dilemmas and gaining the advantages", Journal of Socio-Economics, Vol. 29 No. 5, pp. 471-485.

DOI: 10.1016/S1053-5357(00)00083-4

Riketta, M. (2002), "Attitudinal organizational commitment and job performance: A meta-analysis", Journal of Organizational Behavior, Vol. 23, No. 3, pp. 257-266. DOI: $10.1002 /$ job.141

Rowlinson, S. (2001), "Matrix Organizational Structure, Culture and Commitment: A Hong Kong Public Sector Case Study of Change", Construction Management and Economics, Vol. 19 No. 7, pp. 669-673. DOI: 10.1080/01446190110066137

Sager, J.K., Johnston, M.W. (1989), "Antecedents and Outcomes of Organizational Commitment”, Journal of Personal Selling \& Sales Management, Vol. 9 No. 1, pp. 30-41.

Spreitzer, G.M. (1995), "Psychological empowerment in the workplace: Dimensions, measurement, and validation", Academy of Management Journal, Vol. 3 No. 5, pp. 1442-1465. DOI: $10.2307 / 256865$

Strużyna, J. (2009), "Directions of HRM improvement in public organizations” („Kierunki doskonalenia ZZL w organizacjach publicznych"), in: Frączkiewicz-Wronka, A. (Ed.), Public management - elements of theory and practice (Zarzqdzanie publiczne - elementy teorii i praktyki), Wyd. AE, Katowice, pp. 268-308.

Thomas, K.W., Velthouse, B.A. (1990), "Cognitive elements of empowerment: An "interpretive" model of intrinsic task motivation", Academy of Management Review, Vol. 15 , No. 4, pp. 666-681.

Ugboro, I., Obeng, K. (2000), “Top management leadership, employee empowerment, job satisfaction, and customer satisfaction in TQM organizations: an empirical study", Journal of Quality Management, Vol. 5 No. 2, pp. 247-272.

DOI: 10.1016/S1084-8568(01)00023-2 